\title{
Novel transglutaminase inhibitors reverse the inflammation of allergic conjunctivitis
}

\author{
Joonhong Sohn, ${ }^{1}$ Tae-Im Kim, ${ }^{1}$ Young-Hee Yoon, ${ }^{1}$ Joo-Yong Kim, ${ }^{2}$ and Soo-Youl Kim ${ }^{2}$ \\ ${ }^{1}$ Department of Ophthalmology, Asan Medical Center, Seoul, Republic of Korea \\ ${ }^{2}$ Department of Neuroscience, Weill Medical College of Cornell University and Burke Medical Research Institute, \\ White Plains, New York, USA
}

\begin{abstract}
Steroidal anti-inflammatory drugs induce proteins that inhibit phospholipase $\mathrm{A}_{2}\left(\mathrm{PLA}_{2}\right)$, including uteroglobin and lipocortin-1 (annexin I). Uteroglobin and lipocortin-1 retain several conserved sequences. Based on these sequences, several nonapeptides (antiflammins) were synthesized. These nonapeptides were shown to have anti-inflammatory effects in vitro and in vivo, possibly by inhibiting $\mathrm{PLA}_{2}$. Subsequent research showed that $\mathrm{PLA}_{2}$ is activated by transglutaminase 2 (TGase 2). We hypothesize here that TGase 2 inhibitors may increase the anti-inflammatory efficacy of inhibiting $\mathrm{PLA}_{2}$ activity. To test this theory, we constructed recombinant peptides containing sequences from pro-elafin (for inhibition of TGase 2), and from lipocortin-1, lipocortin-5, and uteroglobin (for inhibition of $\mathrm{PLA}_{2}$ ). The recombinant peptides, which had dual inhibitory effects on purified TGase 2 and $\mathrm{PLA}_{2}$, reversed the inflammation of allergic conjunctivitis to ragweed in a guinea pig model. The present work suggests that novel recombinant peptides may be safe and effective agents for the treatment of various inflammatory diseases.
\end{abstract}

J. Clin. Invest. 111:121-128 (2003). doi:10.1172/JCI200315937.

\section{Introduction}

Inflammation processes are complex biochemical phenomena that are characterized physiologically in tissues by edema, pain, and leukocyte infiltration (1). Currently, the most effective anti-inflammatory drugs are glucocorticoids. Glucocorticoids induce many proteins, such as lipocortins. Lipocortins are inhibitors of phospholipase $\mathrm{A}_{2}\left(\mathrm{PLA}_{2}\right.$; International Union of Biochemistry and Molecular Biology enzyme no. 3.1.1.4 [EC 3.1.1.4]) $(2,3)$. $\mathrm{PLA}_{2}$ plays a key role in the pathogenesis of allergic conjunctivitis (4). In the inflammation process, $\mathrm{PLA}_{2}$ hydrolyzes the acyl-ester bond at the $s n-2$ position of phosphoglycerides (5). This is the first rate-limiting step in the eicosanoid cascade, generating arachidonic acid. Arachidonic acid is converted to prostaglandins and leukotrienes that cause inflammation (6). Therefore, an effective treatment of inflammatory diseases is inhibition of $\mathrm{PLA}_{2}$, blocking both cyclooxygenase and lipoxygenase pathways in the arachidonic acid cascade (6). Steroidal anti-inflammatory drugs inhibit $\mathrm{PLA}_{2}$ by inducing $\mathrm{PLA}_{2}-$ inhibitory proteins, including uteroglobins (a subfamily of secretoglobins) (7) and lipocortin-1 (annexin I) $(3,8)$.

Received for publication May 15, 2002, and accepted in revised form October 8, 2002.

Address correspondence to: Soo-Youl Kim, Department of Neuroscience, Weill Medical College of Cornell University and Burke Medical Research Institute, 785 Mamaroneck Avenue, White Plains, New York 10605, USA. Phone: (914) 597-2500; Fax: (914) 597-2757; E-mail: sykim@burke.org.

Conflict of interest: The authors have declared that no conflict of interest exists.

Nonstandard abbreviations used: phospholipase $\mathrm{A}_{2}\left(\mathrm{PLA}_{2}\right)$; antiflammin (AF); transglutaminase 2 (TGase 2).
Miele et al. identified a region of sequence similarity between uteroglobin and lipocortin-1 (9). Further, they designed several synthetic peptides corresponding to the region of highest similarity between uteroglobin and lipocortin-1. The most effective anti-inflammatory nonapeptides, termed antiflammins (AFs) by Miele et al. (9), corresponded to uteroglobin residues 39-47 and lipocortin-1 residues 246-254. Both peptides were shown to be $\mathrm{PLA}_{2}$ inhibitors in vitro and were effective in a classic model of acute inflammation in carrageenan-induced rat footpad edema (9).

Interestingly, treatment of purified $\mathrm{PLA}_{2}$ with transglutaminase 2 (TGase 2; EC 2.3.2.13) strikingly increased $\mathrm{PLA}_{2}$ activity in vitro. TGase 2-catalyzed conformational changes in $\mathrm{PLA}_{2}$ can be brought about by formation of an intramolecular $\varepsilon$ - $(\gamma$-glutamyl)-lysine crosslink (10) or by incorporation of polyamines (11). These observations suggest that TGase 2-mediated modification may activate $\mathrm{PLA}_{2}$ in vivo, following an influx of calcium. TGase 2 is a calcium-dependent enzyme that catalyzes the covalent cross-linking of the $\gamma$-carboxamide groups of a peptide-bound glutamine residue with the $\varepsilon$-amino group of a peptide-bound lysine residue (12). Several physiological roles for TGase 2 have been demonstrated, such as wound healing (13), fibrosis (14), apoptosis (15), and matrix formation (16). Increased TGase 2 expression has been reported to occur in many inflammatory diseases, such as celiac disease (17), Crohn disease (18), and sporadic inclusion-body myositis (19). Pathological roles of TGase 2 in those diseases might be associated with activation of PLA 2 .

Therefore we hypothesize here that blocking both TGase 2 and $\mathrm{PLA}_{2}$ activities may ameliorate $\mathrm{PLA}_{2}$-medi- 
ated inflammation. To test this hypothesis, a series of new recombinant peptides using sequences from $\mathrm{AFs}$ and pro-elafin (cementoin) were constructed as competitive inhibitors of $\mathrm{PLA}_{2}$ and TGase 2, respectively. Cementoin is a good TGase 2 substrate for anchoring pro-elafin onto matrix proteins (20). Further, it has been demonstrated that sequences derived from pro-elafin serve as competitive reversible TGase inhibitors (21). Here we show that recombinant peptides inhibit $\mathrm{PLA}_{2}$ as well as TGase 2 . We also show that the recombinant peptides abolish the TGase 2-catalyzed activation of $\mathrm{PLA}_{2}$ in vitro and have a pronounced anti-inflammatory effect on allergic conjunctivitis in vivo.

\section{Methods}

Construction of synthetic peptides. Four peptides (A1-A4) were synthesized based on published sequences of AFs from lipocortin-5 (A1), lipocortin-1 (A2), uteroglobins (A3), and the conserved region of AFs (A4) $(9,22)$. Three peptides (E1-E3) were synthesized based on the pro-elafin sequences $(21,23)$. Two recombinant peptide sequences (R1 and R2) were constructed by combining AFs and pro-elafin sequences. E1-E3 and R1-R2 peptides encoded putative TGase 2 substrate domains that will compete with other TGase 2 substrates (21, 23). Two synthetic peptide inhibitors of $\mathrm{PLA}_{2}$ (P1 and P2) were tested for their effectiveness as positive controls $(24,25)$. All the peptides were synthesized and purified by HPLC, and the compositions and concentrations were determined accurately by amino acid analysis (Peptron Co., Taejun, Republic of Korea). All peptides were dissolved in a small volume of PBS (6.7 $\mathrm{mM}$ phosphate, $150 \mathrm{mM} \mathrm{NaCl}[\mathrm{pH} 7.3]$ ) and stored frozen until used.

Inhibitory effect of synthetic peptides on PLA $A_{2}$ in vitro. Using an established assay, we determined the enzymatic activity of $\mathrm{PLA}_{2}$ by measuring the release of $\left[{ }^{14} \mathrm{C}\right]$ arachidonic acid from 1 -acyl-2-[1-14 C]arachidonic acid-glycerophosphoethanolamine (26). To determine the inhibitory activity, $0.18 \mathrm{U}$ of $\mathrm{PLA}_{2}$ (bovine pancreas, EC 3.1.1.4; Sigma-Aldrich, St. Louis, Missouri) was preincubated for 15 minutes with the synthetic peptides $\left(1 \times 10^{-8} \mathrm{M}\right)$ at $37^{\circ} \mathrm{C}$ in $60 \mu$ of assay buffer (75 mM Tris-Cl, pH 9.0, $5 \mathrm{mM} \mathrm{CaCl}, 1 \mathrm{mg} / \mathrm{ml}$ fatty acid-free bovine serum albumin) before adding 1-acyl-2-[1-14C]arachidonic acid-glycerophosphoethanolamine. $1.0 \mathrm{U}$ of $\mathrm{PLA}_{2}$ will hydrolyze $1.0 \mu \mathrm{mol}$ of $\mathrm{L}-\alpha$-phosphatidylcholine to L- $\alpha$-lysophosphatidylcholine and a fatty acid per min. at $\mathrm{pH} 8.0$ at $37^{\circ} \mathrm{C}$. The control was $\mathrm{PLA}_{2}$ preincubated with buffer. After preincubation, $\mathrm{PLA}_{2}$ activity was assayed using sonicated liposomes, prepared as described (27). Forty microliters of 1-acyl-2-[1-14 C]arachidonic acid-glycerophosphoethanolamine (about $2 \times 10^{5}$ disintegrations per minute) was added to the preincubated mixture and incubated for 1 hour at $37^{\circ} \mathrm{C}$. The reaction was terminated by addition of $0.75 \mathrm{ml}$ of Dole's reagent (78\% [vol/vol] $n$-heptane, $20 \%$ [vol/vol] propan-2-ol, and $2 \%[\mathrm{vol} / \mathrm{vol}] 2 \mathrm{M}$ aqueous $\mathrm{H}_{2} \mathrm{SO}_{4}$ ). To extract the liberated $\left[{ }^{14} \mathrm{C}\right]$ arachidonic acid, $0.25 \mathrm{ml}$ of $\mathrm{H}_{2} \mathrm{O}$ was added to the incubated mixture, vortexed, and centrifuged at $1,200 \mathrm{~g}$ for 5 minutes. The upper phase was then transferred to a tube that contained $100 \mathrm{mg}$ of silica gel (230-400 mesh; Sigma-Aldrich) and $0.75 \mathrm{ml}$ of $n$-heptane. The sample was vortexed and centrifuged at $1,200 \mathrm{~g}$ for 5 minutes. The supernatant was collected for scintillation counting. Values are the means of three determinations (SD $<10 \%)$. For studies of the inhibitory peptides, each value is the mean of three separate experiments (SD < $10 \%$ ).

Inbibitory effect of synthetic peptides on TGase 2 in vitro. We determined TGase activity by measuring the incorporation of $\left[1,4-{ }^{14} \mathrm{C}\right]$ putrescine into succinylated casein (12). To determine the inhibitory effects of the peptides, we preincubated $1 \times 10^{-3} \mathrm{U}$ guinea pig liver TGase 2 (EC 2.3.2.13; Sigma-Aldrich) - $1.0 \mathrm{U}$ of which will catalyze the formation of $1.0 \mu \mathrm{mol}$ of hydroxamate per minute from $N$ - $\alpha$-CBZ-Gln-Gly and hydroxylamine at $\mathrm{pH} 6.0$ at $37^{\circ} \mathrm{C}-$ for 15 minutes with the synthetic peptides $\left(1 \times 10^{-8} \mathrm{M}\right)$ in $0.1 \mathrm{ml}$ of buffer containing 0.1 $\mathrm{M}$ Tris-acetate $(\mathrm{pH} 7.5)$ at $37^{\circ} \mathrm{C}$. We then added the TGase/peptide mixture to $0.5 \mathrm{ml}$ of the substrate solution, containing $0.1 \mathrm{M}$ Tris-acetate ( $\mathrm{pH} 7.5$ ), $1 \%$ (wt/vol) succinylated casein, $1 \mathrm{mM}$ EDTA, $10 \mathrm{mM} \mathrm{CaCl} 2,0.5 \%$ (wt/vol) lubrol PX, $5 \mathrm{mM}$ DTT, $0.15 \mathrm{M} \mathrm{NaCl}$, and 0.5 $\mathrm{mCi}\left[1,4-{ }^{14} \mathrm{C}\right]$ putrescine dihydrochloride $(118 \mathrm{Ci} / \mathrm{mol}$; NEN Life Science Product Inc., Boston, Massachusetts, USA). Following incubation at $37^{\circ} \mathrm{C}$ for 1 hour, the reaction was terminated by addition of $4.5 \mathrm{ml}$ of cold $7.5 \%$ (wt/vol) trichloroacetic acid $\left(\mathrm{TCA} ; 4^{\circ} \mathrm{C}\right)$. The TCAinsoluble precipitates were collected onto GF/A (Millipore, Bedford, Massachusetts, USA) glass fiber filters, washed with cold $5 \%$ (wt/vol) TCA, dried, and counted. The control was TGase preincubated with buffer only. Values are the means of three determinations.

Inbibitory effect of synthetic peptides on the activation of $P L A_{2}$ by TGase 2 in vitro. The synthetic peptides $\left(1 \times 10^{-8}\right.$ M) were preincubated with $1 \times 10^{-3} \mathrm{U}$ of TGase 2 and $1.8 \times 10^{-3} \mathrm{U}^{\circ} \mathrm{PLA}_{2}$ in $60 \mu \mathrm{l}$ of assay buffer for $15 \mathrm{~min}$ utes at $37^{\circ} \mathrm{C}$. A negative control was incubated in the absence of TGase, and TGase incubated in the absence of peptides was used as a positive control. After preincubation, $40 \mu$ of 1 -acyl-2-[1-14 C]arachidonic acid-glycerophosphoethanolamine (about $2 \times 10^{5}$ disintegrations per minute) was added to the preincubated mixture, and the assay mixture was incubated for 1 hour at $37^{\circ} \mathrm{C}$. The reaction was terminated by addition of $0.75 \mathrm{ml}$ of Dole's reagent, and the released arachidonic acid was determined as described above.

In vivo experimental model of allergic conjunctivitis. Female guinea pigs of the Hartley strain were selected as in previous reports (e.g., ref. 28). Eighty-six female Hartley guinea pigs (200-250 g) were housed in the animal facilities of the Asan Institute for Life Sciences (Republic of Korea), given guinea pig chow and water ad libitum, and cared for in accordance with the Declaration of Helsinki and the NIH Guide for the Care and Use of Laboratory Animals (Republic of Korea). 
Table 1

Scale for 0 -to-4+ evaluation of clinical signs in experimental conjunctivitis

\begin{tabular}{lcccc} 
Clinical signs & None $(0+)$ & Minimal $(1+)$ & Mild $(2+)$ & Moderate $(3+)$ \\
Conjunctival redness & Absent & Minimal redness & Easily detectable redness & Obvious redness \\
Conjunctival edema & Absent & Minimal edema & Focal-area chemosis & Obvious chemosis \\
\hline
\end{tabular}

Giant ragweed pollen (Ambrosia trifida, $1.0-1.5 \mathrm{mg}$; Sigma-Aldrich) was delivered once a day into the nostrils and the inferior conjunctival fornices of 84 animals on days $1-5$ and $8-12$ with a micropipette calibrated to $10 \mu \mathrm{l}$. On day 15 , immunized guinea pigs were divided into 14 groups, with six in each group. Eleven synthetic peptides, including the new recombinants described here, dexamethasone eye drops (Maxidex, 0.1\% dexamethasone; Alcon-Couvreur, Puurs, Belgium), and antihistamine eye drops (Livostin, levocabastine; Janssen Pharmaceutica, Beerse, Belgium), were used for 13 groups, and no treatment was used for one group. Normal controls were six nonimmunized, untreated guinea pigs. All immunized guinea pigs were challenged with $1.0-1.5 \mathrm{mg}$ of ragweed-pollen powder delivered to the inferior conjunctival fornice on day 15. All the procedures conformed to the experimental model of allergic conjunctivitis described by Merayo-Lloves et al. (28). All synthetic peptides were dissolved in sterile saline $(100 \mu \mathrm{mol} / 40 \mu \mathrm{l}$ concentration). All peptides and dexamethasone eye solutions were administered 3 hours before the last pollen application on day 15,10 minutes after pollen application, and four times thereafter at 3-hour intervals.

Clinical evaluation for anti-inflammatory activity. Conjunctival edema and redness were judged in room light and under an operating microscope (Carl Zeiss, Oberkochen, Germany). The evaluation was performed in a blinded fashion at 20 minutes after allergen challenge. Each clinical parameter was scored on a scale of 0 to $4+(0$ absent, $1+$ minimal, $2+$ mild, $3+$ moderate, $4+$ severe) as described previously (Table 1) (28). Clinical scores of each group (12 eyes per group) were analyzed.

Histology for anti-inflammatory activity. The orbits were exenterated after the animals were killed with $\mathrm{CO}_{2}$ asphyxia, and lower eyelids including inferior fornicial conjunctiva were prepared for the light-microscopic examination. The central part of each specimen was cut sagittally and stained with hematoxylin and eosin. The eosinophils in standardized fields of conjunctival epithelium, immediate subepithelium, and stroma were counted in three nonconsecutive fields for each treatment in each experiment (magnification $\times 400 ; 12$ eyes per group).

Inbibitory effect of synthetic peptides on TGase and PLA activities in vivo. Inferior fornicial and palpebral conjunctiva including conjunctival epithelium and subepithelial stroma were dissected and homogenized by means of a Sonic Dismembranator (Fisher Scientific Co., Pittsburgh, Pennsylvania, USA) in a tenfold volume of ice-cold 0.1 M Tris-acetate (pH 7.5) and $1 \mathrm{mM}$
EDTA, containing $1 \%$ (vol/vol) Triton X-100 and protease cocktail. The homogenates were centrifuged at $10,000 \mathrm{~g}$ for 30 minutes at $4^{\circ} \mathrm{C}$. The supernatant was used for analysis of TGase and $\mathrm{PLA}_{2}$ activities. The assay conditions for TGase and $\mathrm{PLA}_{2}$ were the same as those used for in vitro assays as described above.

\section{Results}

The effect of the 11 synthesized peptides on $\mathrm{PLA}_{2}$ activity is shown in Figure 1a. The PLA 2 activity in the absence of peptides was assigned a value of $100 \%$ (5.57 pmol arachidonyl per hour). AFs (A1-A3) inhibited $\mathrm{PLA}_{2}$ activity by about $40 \%$, while P1 and P2 did not significantly inhibit it (Figure 1a). Pro-elafin peptides (E1-E3) inhibited $\mathrm{PLA}_{2}$ activity by as much as $25 \%$ (Figure 1a). The recombinant peptide (R2) designed

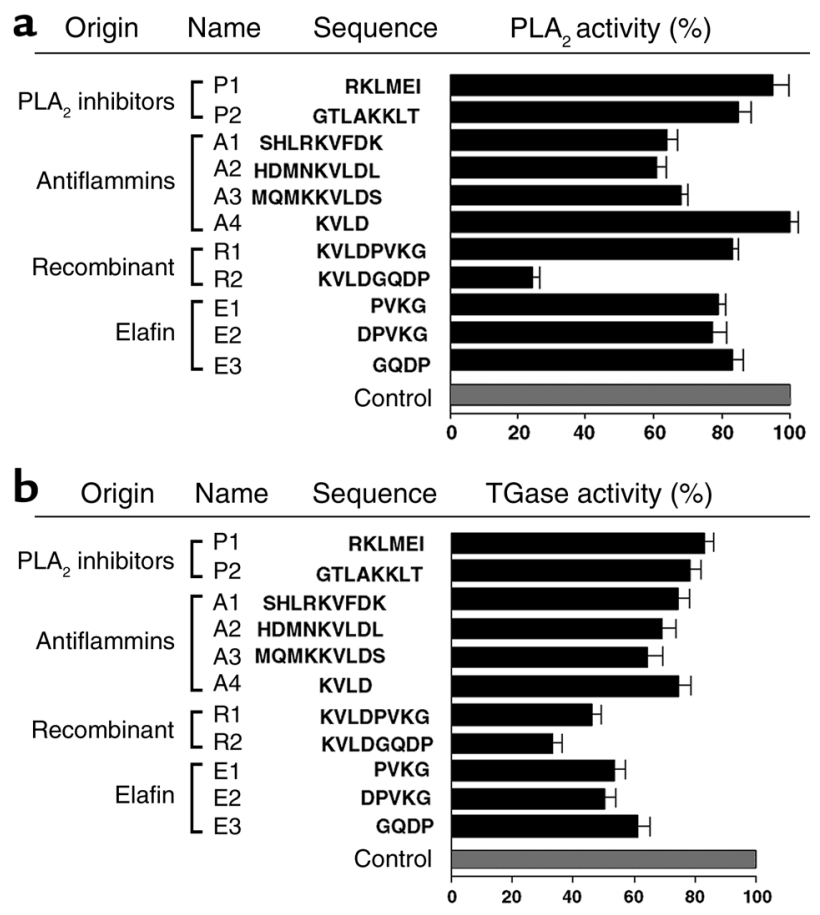

\section{Figure 1}

The effects of various peptides on (a) PLA $_{2}$ activity and (b) TGase 2 activity. (a) Purified PLA $\mathrm{A}_{2}$ was preincubated with the peptides for 15 minutes before assay. The recombinant peptide R2 showed the best inhibitory effect on PLA 2 activity, although most AFs (A1-A3) inhibited PLA $\mathrm{A}_{2}$ activity to some extent. (b) Purified TGase 2 was preincubated with the peptides for 15 minutes before assay. The recombinant peptide R2 showed the best inhibitory effect on TGase 2 activity, although all pro-elafin peptides (E1-E3) inhibited TGase 2 activity to some extent. Data are presented as mean \pm SD from three separate experiments. 
a

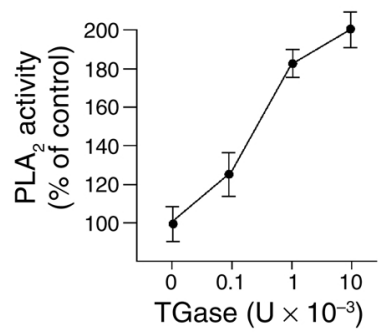

b

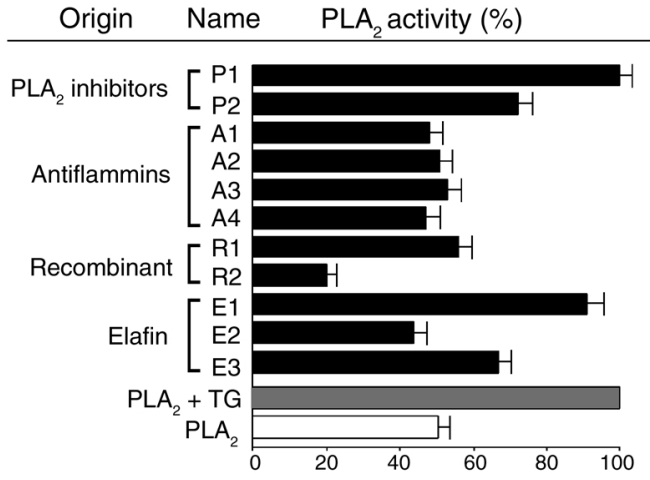

Figure 2

The effects of various peptides on activation of PLA $\mathrm{A}_{2}$ by TGase 2. (a) Purified $\mathrm{PLA}_{2}$ was preincubated with different amounts of TGase 2 for 15 minutes before assay. PLA 2 activity was increased by incubation with TGase 2 in a dose-dependent manner. Data are presented as mean \pm SD from three repeats of each TGase 2 concentration. (b) Purified $\mathrm{PLA}_{2}$ was preincubated with the peptides and $1 \times 10^{-3} \mathrm{U}$ TGase 2 for 15 minutes before assay. The recombinant peptide R2 markedly decreased $\mathrm{PLA}_{2}$ activity, although most AFs (A1-A3) and $\mathrm{E} 3$ inhibited $\mathrm{PLA}_{2}$ activity. Data are presented as mean $\pm \mathrm{SD}$ from three separate experiments.

from the core domains of $\mathrm{AF}$ and pro-elafin inhibited about $75 \%$ of $\mathrm{PLA}_{2}$ activity (Figure 1a). To determine the inhibitory effect of the synthetic peptides on purified TGase 2, the enzyme was preincubated with synthetic peptides in vitro at room temperature for 15 minutes before the TGase assay was started. The activity of TGase 2 incubated without peptides was assigned a value of $100 \%$ (4.89 pmol putrescine per hour) (Figure 1b). Pro-elafin peptides (E1-E3) inhibited TGase 2 by $40-50 \%$ (Figure 1b). P1, P2, and A1-A4 inhibited TGase 2 by about $20-40 \%$ (Figure 1b). R2 inhibited TGase 2 activity by about $70 \%$ and $\mathrm{PLA}_{2}$ activity by about $75 \%$. R1 inhibited TGase 2 activity by about $55 \%$, although it did not significantly inhibit $\mathrm{PLA}_{2}$ activity (Figure 1a).

$\mathrm{PLA}_{2}$ activity was increased by incubation with TGase 2 in vitro as previously reported (19). As the amount of TGase 2 in the mixture was increased, PLA $\mathrm{P}_{2}$ activity increased up to twofold (Figure 2a). The increased $\mathrm{PLA}_{2}$ activity by TGase 2 was assigned a value of $100 \%$ (11.2 pmol arachidonyl per hour). R2 inhibited about $80 \%$ of the total $\mathrm{PLA}_{2}$ activity increased by TGase 2 , while AFs (A1-A4) inhibited about $50 \%$ of the total PLA 2 activity increased by TGase 2 . The effect of $\mathrm{R} 2$ might be due to a combined inhibition of TGase 2 and $\mathrm{PLA}_{2}$ activities (Figure 2b). As shown in Figures 1 and 2, R2 signifi- cantly reduced the $\mathrm{PLA}_{2}$ and TGase 2 activities in comparison with the peptides known to be $\mathrm{PLA}_{2}$ inhibitors.

The effect of the synthetic peptides on the guinea pig allergic conjunctivitis model was determined. In addition to the same set of peptides used in Figures 1 and 2 , dexamethasone and Livostin were employed as positive controls. Clinical evaluation of anti-inflammatory activity was based on the degree of conjunctival edema and redness (see Methods). AFs (A1-A4) and pro-elafin peptides (E1-E3) reduced the clinical inflammatory scores by $10-40 \%$ (Figure $3 \mathrm{a}$ ). R2 reduced the clinical inflammation score by about $50 \%$. This reduction is almost the same as that noted with dexamethasone and Livostin eye drops (Figure 3a; Table 2). We performed histological evaluation by counting eosinophils in the standardized fields of conjunctival epithelium and subepithelial stroma. Interestingly, most peptides, including AFs, Rs, and Es, reduced eosinophil infiltration (Figure $3 \mathrm{~b}$ ). R2 and E2 provided the best protection against inflammation $(90 \%$ and $85 \%$ reduction, respectively) - even better than that shown by
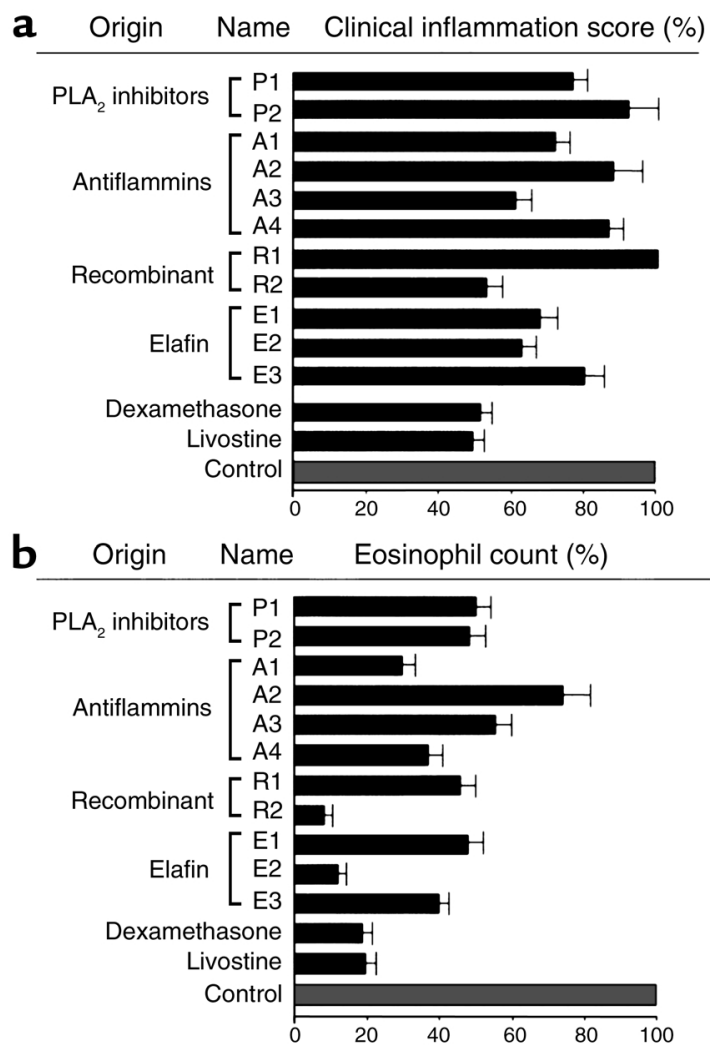

Figure 3

The effects of various peptides on the conjunctival allergic reaction in guinea pigs. (a) The recombinant peptide $\mathrm{R} 2$ reduced clinical allergic signs as much as dexamethasone and Livostin eye drops did. The data are the means of 12 eyes in each group. $P$ values are in Table 2. (b) Eosinophils in the standardized fields of conjunctival epithelium and subepithelial stroma were counted. The recombinant peptide R2 and one peptide of the elafin series (E2) reduced eosinophil infiltration better than dexamethasone and Livostin did. Data are presented as mean of 12 eyes in each group. $P$ values are in the Table 3. 
Table 2

Statistical evaluation of clinical scores shown in Figure 3a

\begin{tabular}{lcccc}
\cline { 3 - 5 } Name & Sequence & \multicolumn{3}{c}{$P$ value compared with: } \\
& & No treatment & Dexamethasone & Livostin \\
P1 & RKLMEI & 0.009 & 0.001 & 0.003 \\
P2 & GTLAKKLT & 0.279 & 0.000 & 0.000 \\
A1 & SHLRKVFDK & 0.003 & 0.007 & 0.009 \\
A2 & HDMNKVLDL & 0.382 & 0.002 & 0.003 \\
A3 & MQMKKVLDS & 0.000 & 0.089 & 0.043 \\
A4 & KVLD & 0.082 & 0.000 & 0.000 \\
R1 & KVLDPVKG & 0.965 & 0.000 & 0.000 \\
R2 & KVLDGQDP & 0.000 & 0.796 & 0.515 \\
E1 & PVKG & 0.001 & 0.017 & 0.012 \\
E2 & DPVKG & 0.000 & 0.050 & 0.039 \\
E3 & GQDP & 0.016 & 0.000 & 0.002 \\
Dexamethasone & 0.000 & &
\end{tabular}

$n=12$; Mann-Whitney test.

dexamethasone and Livostin (Figure 3b; Table 3). Figure 4 shows the histochemical staining pattern of eosinophil infiltration and epithelial edema after treatment with R2, E2, dexamethasone, and Livostin. The inhibitory effect of synthetic peptides on TGase and $\mathrm{PLA}_{2}$ activities in vivo is shown in Figure 5. The activities of TGase and $\mathrm{PLA}_{2}$ in the control were 43.2 $\mathrm{pmol} / \mathrm{mg} / \mathrm{h}$ and $26.4 \mathrm{nmol} / \mathrm{mg} / \mathrm{h}$, respectively. After induction of allergy, $\mathrm{PLA}_{2}$ activity increased fivefold, and TGase activity increased twofold. Treatment with recombinant peptides R2 and E2 reduced activities of TGase and PLA $\mathrm{P}_{2}$ (Figure 5, a and b). Dexamethasone and Livostin treatment resulted in a decrease of $\mathrm{PLA}_{2}$ activity, but not of TGase activity. We have repeated the in vivo experiments (Figures 3-5) and have obtained the same pattern of results (data not shown).

\section{Discussion}

Numerous studies have revealed that steroidal antiinflammatory effects are mediated by the induction of lipocortins (3) and uteroglobins (8), which contain a conserved nonapeptide (AF). Although Hope et al. (29) reported that AFs have no inhibitory effect on $\mathrm{PLA}_{2}$ and no anti-inflammatory activity in vivo, we confirmed the findings of others $(9,30,31)$ that the AFs do indeed have inhibitory activity on $\mathrm{PLA}_{2}$ in vitro and have anti-inflammatory effects on allergic conjunctivitis in vivo (Figure 1). We also confirmed the previous finding (10) that TGase 2 increases $\mathrm{PLA}_{2}$ activity in vitro (Figure 2). Therefore, we hypothesized that blocking both TGase 2 and $\mathrm{PLA}_{2}$ activities might provide maximal protection against inflammation. To test this hypothesis, we constructed recombinant peptides from human lipocortin-1 and pro-elafin as competitive reversible TGase inhibitors (21). These peptides contain $\mathrm{Q}$ and/or $\mathrm{K}$ residue substrates of the intact proteins. The recombinant peptide $\mathrm{R} 2$ showed the greatest inhibitory effect both on TGase 2 and on $\mathrm{PLA}_{2}$ activities in vitro, accompanied by the best antiinflammatory score in vivo.
Interestingly, AF-derived KVLD itself did not inhibit $\mathrm{PLA}_{2}$ activity unless extra amino acids were added to the sequence (Figure 1a). Further, we found that, in addition to inhibiting $\mathrm{PLA}_{2}$, AFs also had some inhibitory activity on TGase 2 in vitro (Figure 1b). This inhibition might be due to the lysine residue of the AFs acting as an acyl acceptor during TGase 2 catalysis and thereby competing with TGase 2 substrates. Analysis of AF peptide sequences showed that AFs contain KVLD whereas pro-elafin contains a similar but reversed sequence (DPVK) (23). Cementoin (see below) is known to be a strong TGase substrate. Therefore, AFs containing the KVLD sequence may be dual-functional competitive inhibitors of TGase 2 and $\mathrm{PLA}_{2}$ in vivo. $\mathrm{R} 2$ contains glutamine and lysine residues as acyl donor and acceptor for TGase catalysis, which might generate synergistic inhibitory effects on TGase 2. $\mathrm{PLA}_{2}$ is a large superfamily of distinct enzymes whose products are important for signaling processes, eicosanoid and platelet-activating factor formation, membrane remodeling, and general lipid metabolism. The $\mathrm{PLA}_{2}$ family is classified into ten groups, including calcium-dependent $\mathrm{PLA}_{2}\left(\mathrm{SPLA}_{2}\right)$ and calcium-independent $\mathrm{PLA}_{2}\left(\mathrm{iPLA}_{2}\right)$, by, e.g., size, secretion characteristics, disulfide content, and molecular characteristics. It should be noted that we tested only bovine pancreas $\mathrm{PLA}_{2}\left(\mathrm{sPLA}_{2}\right.$ group 1$)$ in the in vitro inhibition assay, as did others $(9,22)$. At present, we cannot predict what effects our peptides will have on other members of the $\mathrm{PLA}_{2}$ family.

The structure of pro-elafin consists of two functionally unique domains; one is a TGase substrate (cementoin, amino acids 23-60) and the other is a proteinase inhibitor (amino acids 61-117). The cementoin domain consists of five repeats of VKGQDP that serve as both acyl donor (Q) and acceptor (K) for TGase. This repeat was confirmed to be a very good TGase substrate $(19,20)$. We found similar repeats, such as MKGQDS in guinea pig seminal vesicle protein (SVP-1) (32) and the reversed sequence of EPCQPKVP in human small proline-rich protein (SPR) (33), that are known to be

\section{Table 3}

Statistical evaluation of eosinophil count shown in Figure 3b

\begin{tabular}{lcccc}
\cline { 3 - 5 } Name & Sequence & \multicolumn{3}{c}{$P$ value compared with: } \\
& & No treatment & Dexamethasone & Livostin \\
P1 & RKLMEI & 0.002 & 0.000 & 0.000 \\
P2 & GTLAKKLT & 0.004 & 0.000 & 0.000 \\
A1 & SHLRKVFDK & 0.000 & 0.004 & 0.006 \\
A2 & HDMNKVLDL & 0.161 & 0.000 & 0.000 \\
A3 & MQMKKVLDS & 0.007 & 0.000 & 0.000 \\
A4 & KVLD & 0.001 & 0.028 & 0.045 \\
R1 & KVLDPVG & 0.002 & 0.001 & 0.002 \\
R2 & KVLDGQDP & 0.000 & $0.001^{\mathrm{A}}$ & $0.002^{\mathrm{A}}$ \\
E1 & PVKG & 0.002 & 0.000 & 0.000 \\
E2 & DPVKG & 0.000 & 0.028 & 0.060 \\
E3 & GQDP 0.001 & 0.007 & 0.000 & \\
Dexamethasone & 0.000 & &
\end{tabular}

$n=12$; Mann-Whitney test. ${ }^{\mathrm{A} B e t t e r}$ than dexamethasone and Livostin. 


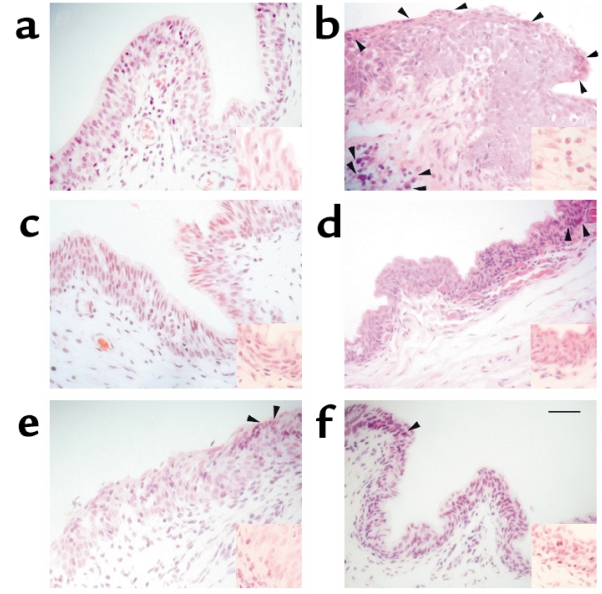

Figure 4

Hematoxylin-and-eosin staining of inferior palpebral and fornicial conjunctiva of guinea pigs. (a) Normal control. (b) Marked eosinophilic infiltration (arrowheads) and epithelial edema induced by ragweed pollen. (c) The recombinant peptide R2 markedly reduced eosinophilic infiltration and epithelial edema. (d) E2 showed mild epithelial edema with few eosinophils. (e and $\mathbf{f}$ ) Dexamethasone and Livostin eye drops showed minimal epithelial edema with few eosinophils. Scale bar, $100 \mu \mathrm{m}$; insets show doubled magnification.

good TGase substrates. Therefore, we adopted the sequences of PVKG and GQDP from cementoin to construct recombinant peptides $\mathrm{R} 1$ and $\mathrm{R} 2$ using the KVLD core sequence of AFs. In accord with our hypothesis, the recombinant peptide containing GQDP (R2) resulted in the best TGase inhibition in vitro and the best anti-inflammatory score in vivo.

TGase 2 is involved in regulating the physiological roles of pro-elafin, uteroglobin, and lipocortin (34-40). Pro-elafin was first discovered in keratinocytes from hyperproliferative human epidermis, such as psoriatic epidermis. However, subsequent research revealed that pro-elafin is a cornified cell envelope component in normal skin (34). Once inflammation activates monocytes (polymorphonuclear cells), an active form of elafin (amino acids 61-117) is released by proteolysis and protects tissues from damage by elastase and proteinase-3 (23). The cementoin peptides remaining in the matrix may have anti-inflammatory effects via competing TGase substrates. The short peptides GQDP and PVKG, derived from cementoin, have previously been demonstrated to be inhibitors of cornified cell envelope formation (21). Uteroglobin was first discovered as a progesterone-induced protein that suppresses sperm antigenicity (35). TGase is involved as a key modulator in modifying the surface of spermatozoa with uteroglobin (36). Therefore, uteroglobin can compete with other TGase substrates, such as $\mathrm{PLA}_{2}$. Lipocortin-1 (annexin I) was discovered as a major glucocorticoid-induced protein (37). Most lipocortins behave as extrinsic membrane proteins, which bind reversibly to phospholipid membranes in a manner that depends on calcium ions. Also, during epithelial cell differentiation, annexin I (lipocortin-1) becomes incorporated into the cornified cell envelope via crosslinking by TGase and cannot be extracted by SDS (38). In buccal epithelium, annexin I constitutes about 10\% of the total barrier envelope proteins, as established by protein sequencing (39). A recent study showed that expression of annexin $I$ is increased at the border between involved and noninvolved skin in psoriasis vulgaris (40). Thus, annexin I itself is involved in the barrier formation as a major building block and possibly also contains an anti-inflammatory function.

Many reports have shown an increase of TGase activity in diseases associated with inflammation. These diseases include celiac disease (17), Crohn disease (18), and sporadic inclusion-body myositis (19). An increase of TGase 2 activity in these diseases might be associated with important physiological regulation such as activation of $\mathrm{PLA}_{2}$. However, the mechanism for aberrant TGase 2 expression is not yet clear. In the inflammatory region, local cytokine levels are changed. Eosinophils are not only the source of cytotoxic and proinflammatory mediators but can also generate cytokines and growth factors, including IL-4, IL-5, and IL-10 as Th2 cytokines, and IFN- $\gamma$ as a Th1 cytokine (41). Inflammatory cytokines such as IFN- $\gamma$ can increase the expression of TGase 2 in small-intestinal cells (42). Consequently, an increase of TGase 2 may cause stimulation of $\mathrm{PLA}_{2}$ activity. In addition to $\mathrm{PLA}_{2}$ activation, TGase 2 is also involved in the adhesion and migration of monocytes (43), which suggests that TGase 2 may accelerate neutrophil adhesion to endothelial cells in the inflammatory lesion. Therefore, a TGase 2 inhibitor might have dual anti-inflammatory properties.

The mucous membrane of the conjunctiva in the ocular surface is continually exposed to a variety of antigens.

a

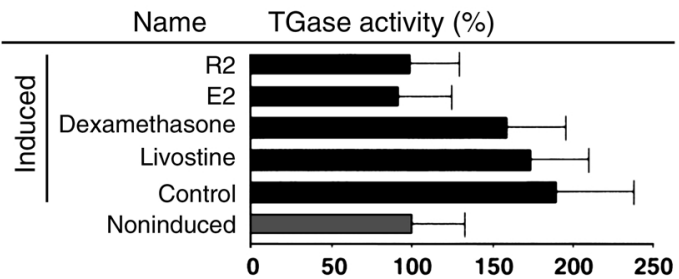

b

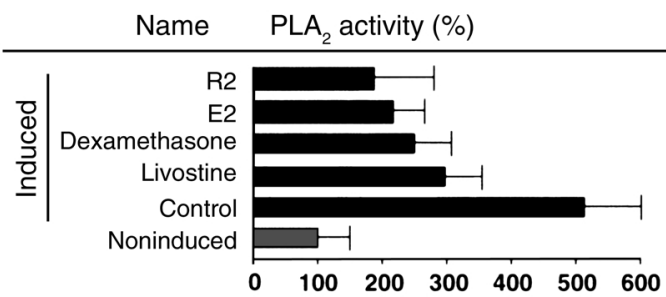

Figure 5

The effects of synthetic peptides, dexamethasone, and Livostin on (a) TGase activity and (b) $\mathrm{PLA}_{2}$ activity in the conjunctiva. After induction of allergy, PLA $\mathrm{A}_{2}$ activity is increased fivefold, and TGase activity is increased twofold. (a) TGase activity is decreased by treatment of R2 and E2. Data are presented as mean \pm SD from three samples. (b) R2 and E2 markedly decrease PLA 2 activity. These peptides are as effective as dexamethasone and Livostin. Data are presented as mean \pm SD from three samples. 
In sensitized individuals, pollen, plant, house-dust mite, or animal-dander allergens dissolved in the tear film cross the conjunctival epithelium and activate substantia propria mast cells, leading to inflammation in conjunctiva, i.e., to allergic conjunctivitis $(44,45)$. The experimental guinea pig allergy model closely resembles human allergic conjunctivitis. The guinea pig conjunctiva is more similar to that of the human than to that of the rat or mouse (28). Short ragweed pollen was used as an antigen to develop conjunctivitis, because it is a "natural allergen" that induces hay fever conjunctivitis in susceptible humans. The pollen was delivered to the ocular and nasal mucosa in a powder form instead of as an injected solution to mimic more closely the human clinical picture found in hay fever rhinoconjunctivitis (28). Toxic eosinophil proteins are present in conjunctiva, cornea, tears, and contact lenses of patients suffering from ocular allergy, suggesting an effector role for the eosinophil in the ophthalmic manifestations of atopy. The present study showed the same trend, with clinical appearance and infiltration of eosinophils. Thus, histological evaluation provided a means for evaluating the effectiveness of the synthesized peptides (Figure 3). AFs and novel recombinant peptides showed antiallergic effects similar to the in vitro inhibition of TGase 2 and $\mathrm{PLA}_{2}$ activity of those peptides. The recombinant peptide $\mathrm{R} 2$ was as effective as dexamethasone and antihistamine eye drops. Interestingly, R2 and E2 reduced eosinophil infiltration (Figures $3 b$ and 4). This pattern was associated with inhibition of TGase 2 activity measured in vitro (Figure 1b) and in vivo (Figure 5). The in vivo results (Figure 5) are consistent with the in vivo clinical inflammation score and eosinophil count (Figure 3), as well as with the in vitro $\mathrm{PLA}_{2}$ inhibitory effect of E2 and R2 (Figure 2b).

$\mathrm{R} 2$ was more effective than dexamethasone and antihistamine eye drops in lowering the histological scores, as judged by counting of infiltrated eosinophils. The eosinophil infiltration was almost completely blocked by the recombinant peptide $\mathrm{R} 2$ (i.e., the score was similar to that of untreated controls). The strong protective effect of $\mathrm{R} 2$ may be due to a synergistic inhibitory effect on $\mathrm{PLA}_{2}$ and TGase 2. Recently other possible physiological actions of AFs in inflammation have been discussed. Topical pretreatment with AF-2 reduces plasma leakage, cell influx, edema, and leukotriene $\mathrm{B}_{4}$ levels in acute inflammatory reaction induced by the topical application of phorbol ester (TPA, 12-O-tetradecanoylphorbol 13-acetate), but not in that induced by topical application of arachidonic acid. This suggests that AFs may affect arachidonic acid mobilization and/or arachidonic acid metabolism by 5-lipoxygenase (46). AFs have little effect on LPS-stimulated expression of E-selectin and ICAM-1 on human leukocytes and human coronary artery endothelial cells (HCAECs). Treatment of HCAEC cultures with AFs did not decrease neutrophil (polymorphonuclear cell) binding to endothelial cells. However, preincubation of polymorphonuclear cells with AFs markedly decreased their adhesion to LPSactivated HCAECs. This suggests that AFs may block leukocyte trafficking in inflammation (47). AF-2 also reduced the adhesion of human promyelocytic leukemia cells to endothelial cells (48).

Although they have potent anti-inflammatory effects, steroids have harmful side effects when excessive doses are prescribed. Therefore, novel recombinant antiinflammatory peptides theoretically have enormous possibilities as potent and safe antiallergic and antiinflammatory drugs. In conclusion, we have shown that rationally designed recombinant peptides that coinhibit both PLA $\mathrm{PL}_{2}$ and TGase 2 are potent antiinflammatory agents, which in some cases are as effective as dexamethasone and Livostin in reducing symptoms of allergic conjunctivitis.

\section{Acknowledgments}

We thank A.J.L. Cooper for critical reading of the manuscript. This work was supported by a grant from Seoul Biomedical Research Institute (Republic of Korea) to J. Sohn.

1.Vickerstaff, J.M., and Bielory, L. 1990. Type I hypersensitivity: atopic allergy. In Understanding allergy sensitivity and immunity: a comprehensive guide. J.M. Vickerstaff and L. Bielory, editors. Rutgers University Press. New Jersey, New Brunswick, Canada. 126-136.

2. Flower, R.J., and Blackwell, G.J. 1979. Anti-inflammatory steroids induce biosynthesis of a phospholipase A2 inhibitor which prevents prostaglandin generation. Nature. 278:456-459.

3. Di Rosa, M., Flower, R.J., Hirata, F., Parente, L., and Russo-Marie, F. 1984. Anti-phospholipase proteins. Prostaglandins. 28:441-442.

4. Li, Q., Luyo, D., Matteson, D.M., and Chan, C. 1998. Suppressive effect of antiflammin-2 on compound 48/80-induced conjunctivitis. Role of phospholipase A2s and inducible nitric oxide synthase. Ocul. Immunol. Inflamm. 6:65-73.

5. Clark, J.D., et al. 1991. A novel arachidonic acid-selective cytosolic PLA 2 contains a $\mathrm{Ca}(2+)$-dependent translocation domain with homology to PKC and GAP. Cell. 65:1043-1051.

6. Vane, J., and Botting, R. 1987. Inflammation and the mechanism of action of anti-inflammatory drugs. FASEB J. 1:89-96.

7. Miele, L., Cordella-Miele, E., and Mukherjee, A.B. 1987. Uteroglobin: structure, molecular biology, and new perspectives on its function as a phospholipase A2 inhibitor. Endocr. Rev. 8:474-490.

8. Klug, J., et al. 2000. Uteroglobin/Clara cell 10-kDa family of proteins: nomenclature committee report. Ann. NY Acad. Sci. 923:348-354.

9. Miele, L., Cordella-Miele, E., Facciano, A., and Mukherjee, A.B. 1988. Novel anti-inflammatory peptides from the region of highest similarity between uteroglobulin and lipocortin1. Nature. 335:726-730.

10. Cordella-Miele, E., Miele, L., and Mukherjee, A.B. 1990. A novel transglutaminase-mediated post-translational modification of phospholipase $\mathrm{A}_{2}$ dramatically increases its catalytic activity. J. Biol. Chem. 265:17180-17188.

11. Cordella-Miele, E., Miele, L., Beninati, S., and Mukherjee, A.B. 1993. Transglutaminase-catalyzed incorporation of polyamines into phospholipase A2. J. Biochem (Tokyo). 113:164-173.

12. Folk, J.E., and Chung, S.-I. 1985. Transglutaminase. Methods Enzymol. 113:358-375

13. Aeschlimann, D., and Thomazy, V. 2000. Protein crosslinking in assembly and remodeling of extracellular matrices: the role of transglutaminases. Connect. Tissue Res. 40:1-27.

14. Griffin, M., Smith, L.L., and Wynne, J. 1979. Changes in transglutaminase activity in an experimental model of pulmonary fibrosis induce by paraquat. Br. J. Exp. Pathol. 60:653-661.

15. Fesus, L., Davies, P.J., and Piacentini, M. 1991. Apoptosis: molecular mechanisms in programmed cell death. Eur. J. Cell Biol. 56:170-177.

16. Aeschlimann, D., and Paulsson, M. 1991. Cross-linking of laminin-nidogen complexes by tissue transglutaminase. A novel mechanism for basement membrane stabilization. J. Biol. Chem. 266:15308-15317.

17. Bruce, S.E., Bjarnason, I., and Peters, T.J. 1985. Human jejunal transglutaminase: demonstration of activity, enzyme kinetics and substrate specificity with special relation to gliadin and celiac disease. Clin. Sci. 68:573-579. 
18. D’Argenio, G., et al. 1995. Transglutaminases in Crohn's disease. Gut. 37:690-695.

19. Choi, Y.-C., Park, G.-T., Steinert, P.M., and Kim, S.-Y. 2000. The increased expression of transglutaminase 1 and 2 are responsible for the sporadic inclusion-body myositis. J. Biol. Chem. 275:88703-88710.

20. Nara, K., et al. 1994. Elastase inhibitor elafin is a new type of proteinase inhibitor which has a transglutaminase-mediated anchoring sequence termed "cementoin". J. Biochem. (Tokyo). 115:441-448.

21. Kim, S.-Y., Park, W.-M., Jung, S.-W., and Lee, J. 1997. Novel transglutaminase inhibitors reduce the cornified cell envelope formation. Biochem. Biophys. Res. Commun. 233:39-44.

22. Perretti, M., et al. 1991. A novel anti-inflammatory peptide from human lipocortin 5. Br. J. Pharmacol. 103:1327-1332.

23. Molhuizen, H.O., et al. 1993. SKALP/elafin: an elastase inhibitor from cultured human keratinocytes: purification, cDNA sequence, and evidence for transglutaminase cross-linking. J. Biol. Chem. 268:12028-12032.

24. Wei, E.T., inventor; Regents of University of California, Oakland, assignee. Anti-inflammatory peptides and treatment to inhibit vascular leakage in injured tissues. US patent 5177 060. January 5, 1993.

25. Okazaki, K., Saito, A., and Sato, M., inventors; Kyowa Hakko Kogyo Co. Ltd., assignee. Phospholipase $\mathrm{A}_{2}$-inhibiting peptides. US patent 4895 931. January 23, 1990.

26. Chang, T.S., et al. 1997. Thromboxane A2 synthase inhibition and thromboxane A2 receptor blockade by2-[(4-cyanophenyl)amino]-3chloro-1,4-naphthalenedione (NQ-Y15) in rat platelets. Biochem. Pharmacol. 54:259-268.

27. Kim, D.K., Kudo, I., and Inoue, K. 1991. Purification and characterization of rabbit platelet cytosolic phospholipase A2. Biochim. Biophys. Acta. 1083:80-88.

28. Merayo-Lloves, J., Calonge, M., and Foster, C.S. 1995. Experimenta model of allergic conjunctivitis to ragweed in guinea pig. Curr. Eye Res. 14:487-494.

29. Hope, W.C., Patel, B.J., and Bolin, D.R. 1991. Antiflammin-2 (HDMNKVLDL) does not inhibit phospholipase A2 activities. Agents Actions. 34:77-80.

30. Li, Q., Luyo, D., Matteson, D.M., and Chan, C.C. 1998. Suppressive effect of antiflammin- 2 on compound 48/80-induced conjunctivitis. Role of phospholipase A2s and inducible nitric oxide synthase. Ocul. Immunol. Inflamm. 6:65-73.

31. Moreno, J. 2000. Antiflammin peptides in the regulation of inflammatory response. Ann. NY Acad. Sci. 923:147-153.

32. Moore, J.T., et al. 1987. The major clotting protein from guinea pig seminal vesicle contains eight repeats of a 24-amino acid domain. Proc. Natl. Acad. Sci. USA. 84:6712-6714.

33. Austin, S.J., et al. 1996. Cloning and regulation of cornifin beta, a new member of the cornifin/spr family. Suppression by retinoic acid recep- tor-selective retinoids. J. Biol. Chem. 271:3737-3742.

34. Steinert, P.M., and Marekov, L.N. 1995. The proteins elafin, filaggrin, keratin intermediate filaments, loricrin, and small proline-rich proteins 1 and 2 are isodipeptide cross-linked components of the human epidermal cornified cell envelope. J. Biol. Chem. 270:17702-17711.

35. Mukherjee, D.C., Agrawal, A.K., Manjunath, R., and Mukherjee, A.B. 1983. Suppression of epididymal sperm antigenicity in the rabbit by uteroglobin and transglutaminase in vitro. Science. 219:989-991.

36. Luconi, M., et al. 2000. Uteroglobin and transglutaminase modulate human sperm functions. J. Androl. 21:676-688.

37. Wallner, B.P., et al. 1986. Cloning and expression of human lipocortin, a phospholipase $\mathrm{A} 2$ inhibitor with potential anti-inflammatory activity. Nature. 320:77-81.

38. Moore, K.G., and Sartorelli, A.C. 1992. Annexin I and involucrin are cross-linked by particulate transglutaminase into the cornified cell envelope of squamous cell carcinoma Y1. Exp. Cell Res. 200:186-195.

39. Lee, C.H., et al. 2000. Small proline-rich protein 1 is the major component of the cell envelope of normal human oral keratinocytes. FEBS Lett. 477:268-272.

40. Sato-Matsumura, K.C., et al. 1996. Localization of annexin I (lipocortin I, p35) mRNA in normal and diseased human skin by in situ hybridization. Arch. Dermatol. Res. 288:565-569.

41. Lamkhioued, B., et al. 1996. Synthesis of type 1 (IFN- $\gamma$ ) and type 2 (IL-4, IL-5, and IL-10) cytokines by human eosinophils. Ann. NY Acad. Sci. 796:203-208.

42. Kim, S.-Y., Jeong, E.-J., and Steinert, P.M. 2002. Interferon- $\gamma$ induces transglutaminase 2 expression in rat small intestinal cells. J. Interferon Cytokine Res. 22:677-682.

43. Akimov, S.S., and Belkin, A.M. 2001. Cell surface tissue transglutaminase is involved in adhesion and migration of monocytic cells on fibronectin. Blood. 98:1567-1576.

44. Anderson, D.F. 2001. Management of seasonal allergic conjunctivitis (SAC): current therapeutic strategies. Clin. Exp. Allergy. 31:823-826.

45. Lloret, S., and Moreno, J.J. 1995. Effects of an anti-inflammatory peptide (antiflammin 2) on cell influx, eicosanoid biosynthesis and oedema formation by arachidonic acid and tetradecanoyl phorbol dermal application. Biochem. Pharmacol. 50:347-353.

46. Zouki, C., Ouellet, S., and Filep, J.G. 2000. The anti-inflammatory peptides, antiflammins, regulate the expression of adhesion molecules on human leukocytes and prevent neutrophil adhesion to endothelial cells. FASEB J. 14:572-580.

47. Moreno, J.J. 2001. Antiflammin-2 prevents HL-60 adhesion to endothelial cells and prostanoid production induced by lipopolysaccharides. J. Pharmacol. Exp. Ther. 296:884-889.

48. Leonardi, A. 2002. The central role of conjunctival mast cells in the pathogenesis of ocular allergy. Curr. Allergy Asthma Rep. 2:325-331. 